\title{
Verbal explication of (intra-)interevent causal relations in the story-telling: Comparative study of primary language-impaired and typically-developed pre-schoolers
}

Aleksandr N. Kornev

St. Petersburg State Pediatric

Medical University, Russia
Ingrida Balčiūnienè

\author{
St. Petersburg State Pediatric \\ Medical University, Russia \\ Vytautas Magnus University, Lithuania
}

\begin{abstract}
The current study aimed at evaluating children's ability to explicate verbally the cause-and-effect relations between the events, sequentially organized actions of the characters and their goal-outcome connections. The subjects of our study, i.e. 12 typically-developing (TD) and 12 primarily language-impaired (PLI) Russian preschoolers (mean age 76 months) were asked to tell a story according to a picture sequence. A dual analysis of the verbal explication of causal relations was carried out: 1) during the semantic quantitative analysis of narrative coherence, two types of relations between the events or the characters' actions were estimated: (a) verbally explicated causal relations and (b) semantic relations explicated by sequencing the actions following the "post hoc ergo propter hoc" presupposition (Sanders, 2005); 2) an analysis of the linguistic causal relations was based on a distribution of causal vs. non-causal connectives, such as conjunctions and discourse markers, in the narratives. The statistical analysis revealed significantly infrequent use of causal connectives in the PLI children if compared to the TD peers. As for the semantic relations, the score for the causal relation index was significantly lower in the PLI children than in the TD peers, contrary to the score for the semantic relation index. Among the linguistic devices used for an explication for causal relations, however, only the percentage of causal conjunctions was significant between the groups.
\end{abstract}

Keywords: language acquisition, language impairment, coherence, discourse markers

\section{Introduction}

"Narrative imitates life, life imitates narrative," J. Bruner has said, and this profound statement figuratively illustrates the key role of the causality concept in understanding the nature of a true narrative. The early joint attempts of children 
and their parents to construct a plausible story about their life events are the first step into the understandable world. To investigate a development of this ability, one of the most relevant methods is a story-telling according to picture sequences which has been traditionally employed as a language and oral discourse assessment tool (Bishop, 2004; Justice et al., 2010; Schneider, Dubé \& Hayward, 2006; Stein \& Albro, 1997; Stein \& Glenn, 1975). A narrative should be treated from the twofold perspective: a) as a text of the given discourse genre and b) as a process of generating a verbal story. The latter is a multistep cognitive and verbal activity. In a fiction narrative production according to pictures, the initial steps are to realize the sense of the whole pictured story, to animate it and to chunk implicitly this initially unstructured image into events. The next and even more challenging steps include a verbalization of these chunks according to the narrative template and a verbal explication of the causal relations between the actions of the characters. This effortful task is closely related to planning, sequencing abilities and verbal reasoning activity that may result in the construction of a sufficiently vs. insufficiently coherent narrative. We term this 'skills of the coherent narration' and distinguish it from an ability to produce a grammatically correct cohesive text.

Most studies in narrative development have been devoted to text cohesion (as part of a narrative microstructure), for example, in the language disordered children, there are multiple pieces of evidence of their weakness in the narrative micro- and/or macrostructure (Blom \& Boerma, 2016; Boerma, Leseman, Timmermeister, Wijnen, \& Blom, 2016; Colozzo, Gillam, Wood, Schnell, \& Johnston, 2011; Duinmeijer, de Jong, \& Scheper, 2012; Reuterskiöld, Hansson, \& Sahlén, 2011; Sheng, Zhang, Jiang, de Villiers, Lee, \& Liu, 2017; Squires, Lugo-Neris, Peña, Bedore, Bohman, \& Gillam, 2014). In most of the given studies, the content and its structure (story structure, episode structure, etc.) were analyzed. Much less is still known about coherence in narrative production. The recent findings have evidenced that a skilled narrator is usually proficient in establishing the logical relations in his/ her storytelling and in monitoring its appropriateness. One of the main challenges for children acquiring narrative competence is to master the skills to verbalize explicitly logical relations. Hence, we will try to find the developmental changes manifested in storytelling skills of typically-developing (TD) children and their primarily language-impaired (PLI) peers.

Primary language impairment (PLI) is recognized as a developmental language disorder where the levels of phonological, lexical and syntactic development significantly backward from the chronological age, while nonverbal intelligence, vision, and hearing are normal (Kornev, 2006). This term is relevant to the "specific developmental disorders of speech and language" in the ICD-10 
(the $10^{\text {th }}$ revision of the International Statistical Classification of Diseases and Related Health Problems, a medical classification list by the World Health Organization).

The current study aimed at evaluating children's ability to verbally explicate cause-and-effect relations between the events, sequentially organized actions of the characters, and their goal-outcome connections. In other words, we studied the learning to construct "a causal chain from the opening to the closing of the story" (Trabassco \& Sperry, 1985, p. 595) in TD and clinical population.

\section{Materials and methods}

\subsection{Participants}

Participants with the PLI (12 children, mean age 77 months, attending state kindergartens in St. Petersburg, Russia) were selected from a large group of clinically-referred cases investigated in the previous study (Kornev \& Balčiūnienė, 2017); the inclusion criterion was a normal non-verbal intelligence Raven's Colored Progressive Matrices Test (1998); the exclusion criterion was hearing or/ and visual impairment. The PLI children had received a two-year-course of speech therapy (five sessions a week) at a state kindergarten they attended; nevertheless, in their speech data numerous phonetic, lexical, and grammatical errors occurred. The control group included 12 TD peers randomly selected from the same kindergartens.

For all the participants, informed consent was obtained from their parents. An approval from the Ethical Commission of St. Petersburg State Pediatric Medical University was received.

\subsection{Procedure}

The study employed the Russian Assessment Instrument for Narratives - RAIN (Balčiūnienè \& Kornev, 2016, 2019; Kornev \& Balčiūnienè, 2014, 2015, 2017). The main methodological sources for the elaboration of the RAIN were Stein and Glenn (1975), Stein and Albro (1997), Schneider, Dubé, and Hayward (2006), and Gagarina, Klop, Kunnari, Tantele, Välimaa, Balčiūnienė, Bohnacker and Walters (2012). The picture sets (Fig. 1) have been developed in the framework of the COST Action IS0804 Language Impairment in a Multilingual Society: Linguistic Patterns and the Road to Assessment (http://www.bi-sli.org). 


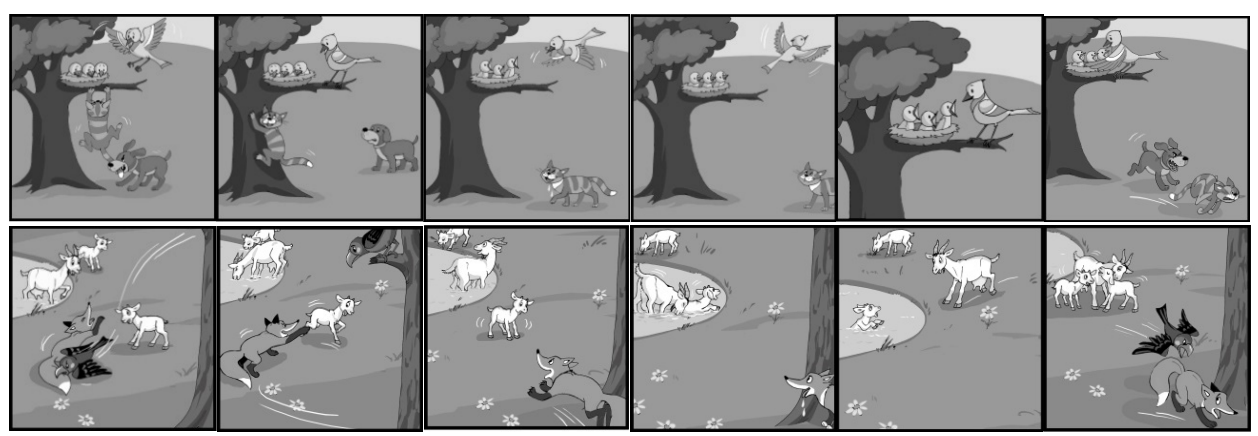

Fig. 1. Visual stimuli. The Baby-Birds and The Baby-Goats

Each set consisted of six colored wordless pictures $(10 \times 10 \mathrm{~cm})$. Despite a congruence between the scripts and the pictorial content, The Baby-Goats set is considered to be more complex to perceive because of slightly overlapping episodes and an additional subplot (Kornev \& Balčiūnienè, 2014). This enabled us to control for story complexity and to evaluate its impact on the narrative production (more on this, see Kornev \& Balčiūnienè, 2017).

During an individual assessment, after a short warm-up, participants performed two tasks (story-telling and retelling); both tasks were followed by ten comprehension questions (retelling and comprehension were not included in the current study). The sessions of the $1^{\text {st }}$ and the $2^{\text {nd }}$ task were separated by a few minutes of spontaneous talk between the experimenter and the child. The order of the tasks presented in the $1^{\text {st }}$ and the $2^{\text {nd }}$ sessions was counterbalanced regarding the story complexity (The Baby-Birds vs. The Baby-Goats) and narrative mode (story-telling vs. retelling). Although the data used for the analysis were collected by different experimenters, they were instructed by the same supervisor (a co-author of the paper) and underwent the same training on the procedures. The sessions were audio-recorded and transcribed for further (pragma-)linguistic analysis.

\subsection{Measures analyzed}

A dual analysis of the verbal explication of causal relations was carried out, i.e. 1) semantical and 2) causal links within each of the narratives were analyzed.

\subsubsection{Semantic quantitative measures of narrative coherence}

For the first part of the study (the semantic quantitative analysis of the narrative coherence), two types of relations between the events or the characters' actions were 
estimated: i.e. (a) causal relations verbally explicated by using specific content (1) or functional (2) words and (b) semantic relations explicated by sequencing the actions (3) following the "post hoc ergo propter hoc" presupposition (Sanders, 2005).

1) Kozlenok chutj ne utonul. Papa ego vytashchil.

'The baby-goat was almost sunk. [His] father saved him.'

2) I papa byl rad, chto kozlenok byl spasen.

'And the father was happy that [his] baby-goat was saved.'

3) Prishel kot. I zakxotel pouzhinatj. Zalez na derevo.

'A cat came. And [he] decided to have a dinner. [He] climbed up the tree.'

First, the total number of semantically related pairs (SRPs) was estimated in the text-samples, originally elaborated by experts for the retelling task (Gagarina et al., 2012) (Fig. 2).

\begin{tabular}{|l|l|}
\hline The SRPs in the text-sample & \multicolumn{1}{|c|}{ Events (characters' actions/ internal states) } \\
\hline 1. Two baby-goats and their mother were walking around. \\
\hline 2. The baby-goat-1 started eating grass. \\
\hline 3. The baby-goat-2 came to the pond and fell into the water. \\
\hline 4. The baby-goat-2 got scared. \\
\hline 5. The mother-goat saw the baby-goat-2 scared. \\
\hline 6. The mother-goat jumped into the water to help the \\
baby-goat-2.
\end{tabular}

Fig. 2. Semantically related pairs in the text-sample elaborated for retelling The Baby-Goats 
During the data analysis, the total number of the SRPs produced by the participants was estimated in each of the stories. Then, the individual score of the SRPs produced in the stories (in comparison to the text-samples) was calculated. Finally, two indexes of the semantic relations explication were estimated and compared between the groups. The first one, the Causal Relation Index (CRI), was calculated by dividing the total number of the child's causal links (such as those given in Examples 1 and 2) by the total number of SRPs in the text-sample. The second one, the Sequential Relation Index (SRI), was calculated by dividing the total number of the child's sequential links (such as those given in Example 3) by the total number of SRPs in the text-sample.

\subsubsection{Pragmalinguistic measures of narrative coherence}

Following several previous linguistic studies in a discourse coherence acquisition (Cain, 2003; Cain \& Oakhill, 1996; Habermas \& de Silveira, 2008; Peterson \& McCabe, 1991; Pinto, Tarchi, \& Bigozzi, 2015, 2016; Sah, 2013; Shapiro \& Hudson, 1991), causal connectives were analyzed as pragmalinguistic measure of narrative coherence. First, we classified all the connectives into conjunctions and discourse markers. Both conjunctions and discourse markers were further classified into causal and non-causal. Then, we estimated individual percentages of the (a) causal conjunctions (such as that as in Example 4), (b) non-causal conjunctions (such as that as in Example 5), (c) causal discourse markers (such as those as in Example 6), and non-causal discourse markers (such as that as in Example 7).

4) Mama reshila najti chervjaka $\underline{\mathbf{i}}$ uletela.

'The mother decided to find a worm and [she] flew away.'

5) Zhili-byli ptenchiki $\underline{\boldsymbol{i}}$ mama.

'There were baby-birds and [their] mother.'

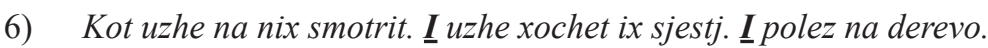

'The cat is looking already at them. And [he] wants to eat them. 'And [he] started climbing up the tree.'

7) Zhila-byla mama ptica. I ptenchiki tozhe byli.

'[There] was a mother-bird. And chicks also were [there].'

\section{Results}

\subsection{The semantic devices for a narrative coherence}

Even at first glance, narratives produced by the PLI subjects seem to be much less elaborated in comparison to those produced by the TD peers. For example, the 
Verbal explication of (intra-)interevent causal relations in the story-telling...

story produced by the TD subject (1) contains 10 events, three sequential links and four causal links verbalized.

Zhili-byli teljatki. I mama koza. Mama koza uvidela, chto ee yagnenok upal v vodu. I zaprygnula v vodu, chtoby ego vytashchitj. A lisa uvidela kozljatok. Kogda mama ego vytashchila, on vyshel na travu. A mama koza v eto vremja smotrela nazad. Vyprygnula lisa. Skhvatila telenka, poka mama koza pila vodu. A v eto vremja podgljadyval orel... chto lisa trogaet yagnenka. Podletel $k$ lise i vzjal ee za khvost. Potom mama koza ... ee teljatki byli spaseny. A orel pognalsja za lisoj.

'There were calves. And [their] mother-goat. The mother-goat saw her lamb fell into the water. And [she] jumped into the water to pull him out. And the fox saw the baby-goats. When the mother pulled him out, he went out onto the grass. And the mother-goat then was looking backward. The fox jumped out. [She] grabbed the calf while the mother-goat was drinking water. The meantime, the eagle was spying... the fox touched the lamb. [He] flew up to the fox and took her tail. Then, the mother-goat... Her calves were saved. And the eagle chased the fox.'

The story produced by the PLI subject (2) contains six events and two sequential links verbalized.

Kozlenok kupalsja v rechke. Mama ego kushala travku. Papa smotrel za kozlenkom. Kozlenok. Kozlenok, navernoe, chutj ne utonul. Papa ego vytashchil... oj, mama. Mama vytashchil. Lisa smotrela za kozlenkom. Vyskochila i pojmala ego. Potom naletela vorona na lisu. I lisa ne mogla pojmatj ego. Potom kozlenok prishel k mame s papoj, a vorona za lisoj pognalasj.

'The baby-goat was swimming in the river. His mother was eating grass. The father was looking after the baby-goat. The baby-goat. The baby-goat probably was nearly sunk. The father pulled him out... ups, the mother. The mother pulled [him] out. The fox was spying the baby-goat. [She] jumped out and caught him. Then, a raven flew at the fox. And the fox could not catch him. Then the baby-goat went to the mother and father, and the crow chased the fox.'

In Figure 3, the events and the SRPs verbalized by the TD (1) and the PLI (2) child are presented in comparison to the text sample given in Figure 2.

One can see (Fig. 3) that the PLI child verbalized fewer episodes and SRPs in comparison to the TD peer, and the SRPs were limited to the sequential links. Moreover, the sequential links were explicated by a discourse marker then; subordinating temporal clauses (such as when ..., after..., while...) were not produced. In the TD child's narrative, besides the discourse markers, we found one subordinating causal clause and two temporal ones. 


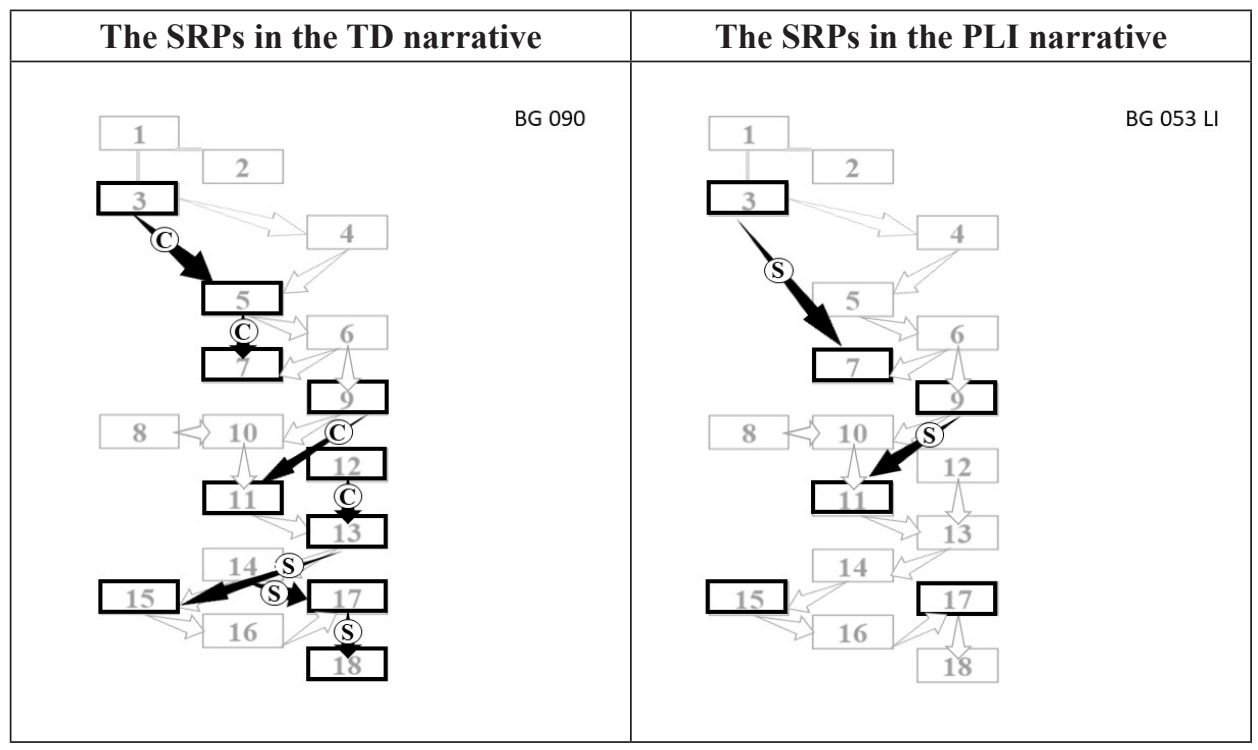

Fig. 3. The SRPs in the TD vs. PLI child's The Baby-Goats narrative (in comparison to the text-sample, see Fig. 2).

In the PLIs, from 0/16 to 7/16 SRPs per story where produced, while in the TDs, this number reached 10/16. However, the group and story complexity variables had a different impact on the score of the CRI and the SRI (Fig. 4).
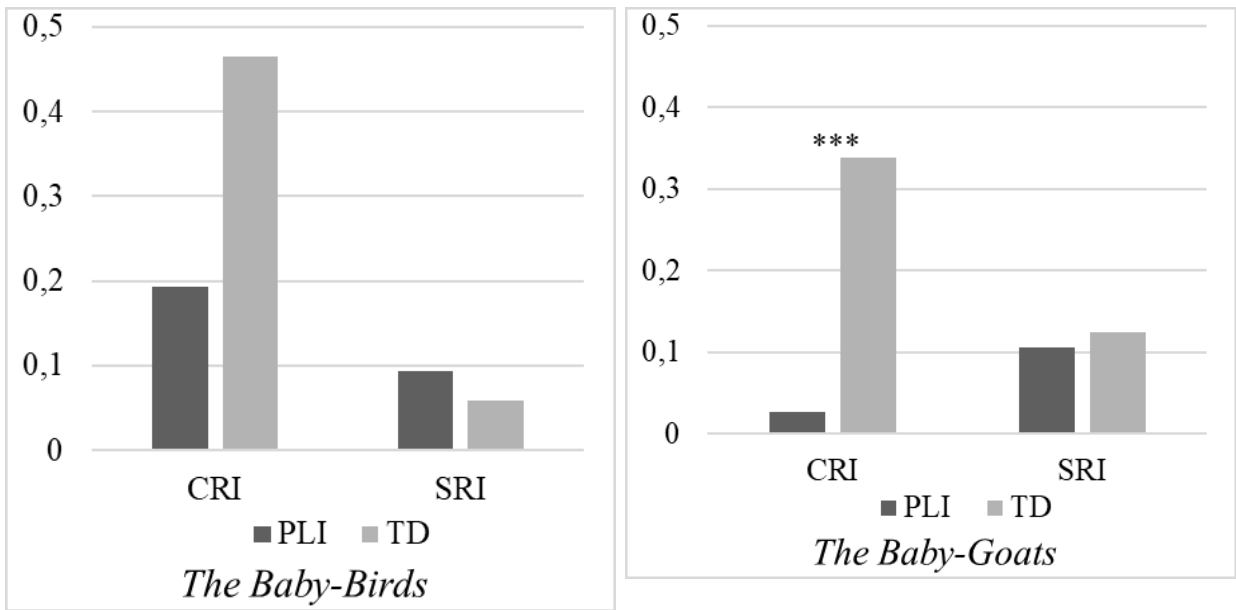

Fig. 4. The CRI and SRI score in the TD and PLI children 
When telling a story according to the easier sequence The Baby-Birds, both TD and PLI participants used more causal links and fewer semantic links, in comparison to the more complex sequence The Baby-Goats. However, from this perspective, The Baby-Birds narratives did not reveal any significant differences between the groups. The Baby-Goats narratives, to the contrary, significantly ( $p$ $\leq 0.001$ ) differentiated the groups on the CRI score; the SRI score was similar for both the TD and PLI participants.

\subsection{The pragma-linguistic devices of a narrative coherence}

Among the coherence devices, causal coordinating and causal subordinating conjunctions turned out to be used differently between the TD and PLI children (Fig. 5).
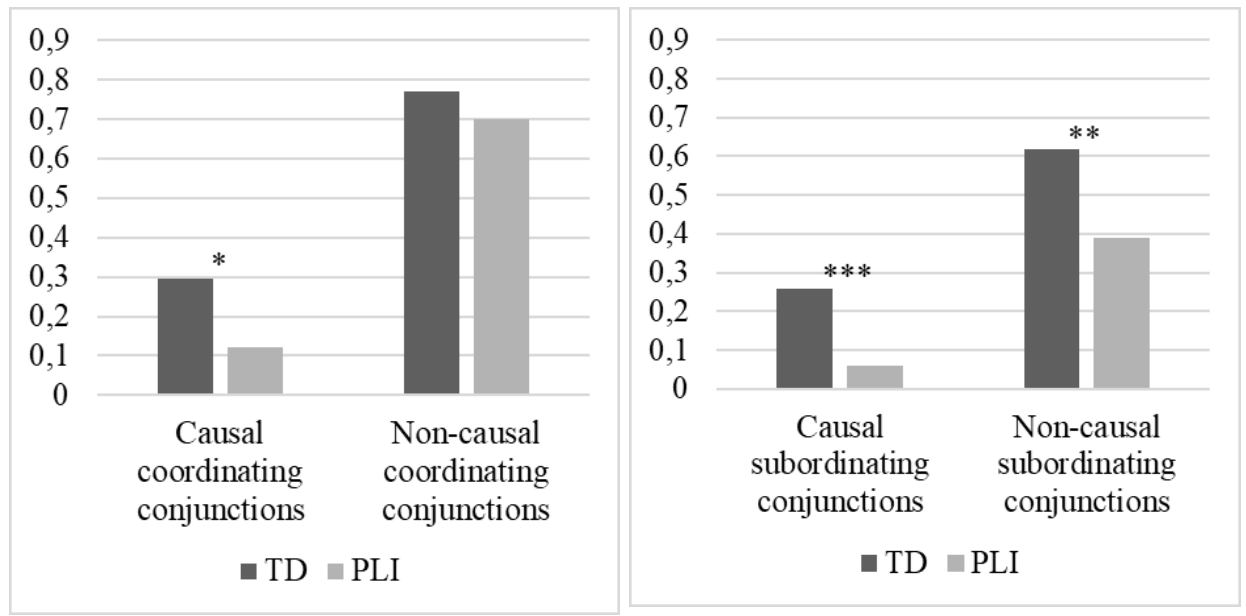

Fig. 5. The distribution of coordinating and subordinating conjunctions in the TD and PLI children

Although the coordinating conjunctions were generally more frequent than the subordinating ones in both the TD and PLI groups, percentage of both coordinating and subordinating causal conjunctions differed between the groups ( $p \leq 0.05$ and $p \leq 0.001$, respectively). Percentage of non-causal subordinating conjunctions was also significantly different between the groups $(p \leq 0.01)$. This result confirmed the observation that syntactic complexity (e.g. the Subordination index, see Newman \& McGregor, 2016; Scott, 1988) might be a valid diagnostic measure for the PLI, especially when evaluating causal clauses. 
Discourse markers, unexpectedly, did not reveal any statistical differences between the groups (Fig. 6).

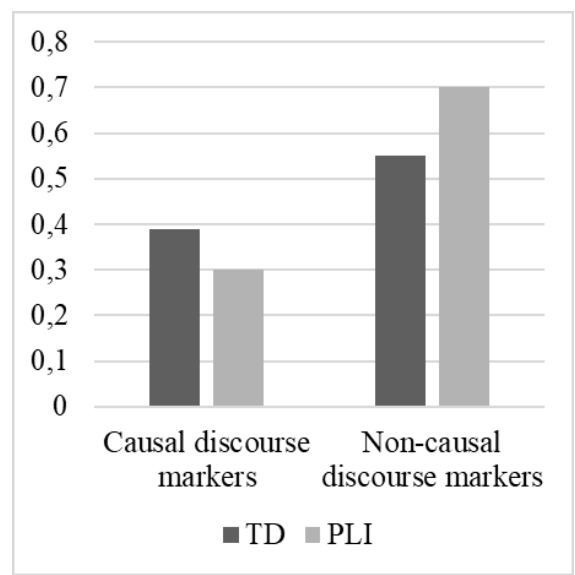

Fig. 6. The distribution of discourse markers in the TD and PLI children

Both TD and PLI participants used more non-causal discourse markers and fewer causal ones. Percentage of causal discourse markers was much lower than that of non-causal ones in the PLI group but the difference was not significant.

\subsection{Differences in the narrative coherence between the TD and PLI children}

To sum up, the statistical analysis revealed significantly less frequent use of causal connectives in the PLI children, as compared to the TD peers. As for the semantic relations, the CRI score was significantly lower in the PLI children than in the TD peers, contrary to the SRI score (Tab. 1).

Tab. 1. Linguistic and semantic measures in the TD and PLI children's narratives

\begin{tabular}{|l|c|c|c|c|c|}
\hline \multirow{2}{*}{ Variables } & \multicolumn{2}{|c|}{ TD } & \multicolumn{2}{c|}{ PLI } & Sig. \\
\cline { 2 - 6 } & $\boldsymbol{M}$ & $\boldsymbol{S D}$ & $\boldsymbol{M}$ & $\boldsymbol{S D}$ & $\boldsymbol{p}$ value \\
\hline $\begin{array}{l}\text { A percentage of causal coordinating conjunc- } \\
\text { tions among all coordinating conjunctions }\end{array}$ & 0.295 & 0.31 & 0.122 & 0.18 & 0.05 \\
\hline $\begin{array}{l}\text { A percentage of non-causal coordinating con- } \\
\text { junctions among all coordinating conjunctions }\end{array}$ & 0.77 & 0.34 & 0.70 & 0.31 & $\mathrm{~ns}$ \\
\hline
\end{tabular}


Verbal explication of (intra-)interevent causal relations in the story-telling...

\begin{tabular}{|l|c|c|c|c|c|}
\hline \multirow{2}{*}{ Variables } & \multicolumn{2}{|c|}{ TD } & \multicolumn{2}{c|}{ PLI } & Sig. \\
\cline { 2 - 6 } & $\boldsymbol{M}$ & $\boldsymbol{S D}$ & $\boldsymbol{M}$ & $\boldsymbol{S D}$ & $\boldsymbol{p}$ value \\
\hline $\begin{array}{l}\text { A percentage of causal subordinating conjunc- } \\
\text { tions among all subordinating conjunctions }\end{array}$ & 0.26 & 0.31 & 0.06 & 0.17 & 0.001 \\
\hline $\begin{array}{l}\text { A percentage of non-causal subordinating } \\
\text { conjunctions among all subordinating con- } \\
\text { junctions }\end{array}$ & 0.62 & 0.31 & 0.39 & 0.49 & 0.01 \\
\hline $\begin{array}{l}\text { A percentage of causal discourse markers } \\
\text { among all discourse markers }\end{array}$ & 0.39 & 0.19 & 0.30 & 0.33 & $\mathrm{~ns}$ \\
\hline $\begin{array}{l}\text { A percentage of non-causal discourse markers } \\
\text { among all discourse markers }\end{array}$ & 0.55 & 0.22 & 0.70 & 0.33 & $\mathrm{~ns}$ \\
\hline $\begin{array}{l}\text { A percentage of CRI in comparison to the } \\
\text { text-sample }\end{array}$ & 0.40 & 0.21 & 0.16 & 0.14 & 0.01 \\
\hline $\begin{array}{l}\text { A percentage of SRI in comparison to the } \\
\text { text-sample }\end{array}$ & 0.09 & 0.09 & 0.09 & 0.13 & $\mathrm{~ns}$ \\
\hline
\end{tabular}

\section{Discussion}

It is common knowledge that text (oral or written) comprehension, besides speech decoding, also involves anticipation and inferences based on individual's knowledge. The same is true for discourse production. In the settings of joint attention, the narrator usually verbalizes his/ her message only partially and relies on the expectation that the remaining part of the content is evident for a listener. In daily written or oral communication, this phenomenon is recognized as the presupposition (Horn, 1997) or the theme-rheme model (Halliday, 1994). Children, additionally, employ implications quite often when they struggle with verbalizing the content. Storytelling according to picture sequence to an adult listener in the settings of joint attention arranges contradictory circumstances. Both the child and adult see the pictures and, thus, the child telling the story may expect the listener to extract some details of the content from the pictures. The more limited the child is in constructing a verbal text, the more he/ she tends to implicate without overt verbalizing. The simplest way to implicate causal relations is to put them sequentially and suppose that post hoc sed propter hoc. This strategy is considered to be typical at the very initial stages of narrative development (Hedberg \& Stoel-Gammon, 1986). Hence, to assess the child's ability to construct a coherent narrative, we should consider not only explicated causal relations but also the implications. In the few publications devoted to causal relations in the narrative, usually only verbal means of explicated 
relations have been discussed. Specifically, a comparison between TD and clinical populations have revealed that specifically language-impaired (SLI) children used causal connectives much less frequently that conjoining and time ones (Epstein \& Phillips, 2009), they tended to focus more on story structure than on causal connectivity (Hayward, Gillam, \& Lien, 2007) and they more often used connectives in a way that violated causal relations in the story (Tribushinina, Dubinkina, \& Sanders, 2015) in comparison to the TD peers. Studies in bilingual clinical populations have evidenced that Russian-Hebrew bilingual SLI children verbalized fewer enabling and physical relations in their narratives in comparison to their bilingual TD peers (Fichman, Altman, Voloskovich, Armon-Lotem, \& Walters, 2017).

\section{Conclusion}

Results of the study shed light on the ability of primarily language-impaired children to explicate verbally causal relations in storytelling and highlighted the main flaws of this skill. Hence, the PLI children tended to avoid an explication and to rely on the context of joint attention. First, semantically related pairs of events (characters' actions and states) were much less numerous in the PLI narratives in comparison to those told by the TD peers. Second, among the semantic links between the events, the sequential ones prevailed, while the causal ones were explicated extremely rarely. Considering the fact that generally story grammar (story structure and episode completeness) rather did not discriminate between the PLI and TD children (Balčiūnienè \& Kornev, 2019), analysis of causal relations seems to be a more sensitive and relevant approach to narrative assessment in clinical populations than the traditional story grammar (macrostructural) analysis.

\section{References}

Balčiūnienė, I. \& Kornev, A. N. (2016). Doing new things with language: Narrative language in SLI preschoolers. Estonian Papers in Applied Linguistics, 12, 25-42.

Balčiūnienè, I. \& Kornev, A. N. (2019). Evaluation of narrative skills in language-impaired children: Advantages of a dynamic approach. In E. Aguilar-Mediavilla, L. Buil-Legaz, R. López-Penadés, V. Sánchez-Azanza, \& D. Adrover-Roig (Eds.), Atypical Language development in Romance Languages, (pp. 127-141). Amsterdam: John Benjamins Publishing Company.

Bishop, D. V. M. (2004). Expression, Reception and Recall of Narrative Instrument (ERRNI). London, UK: Psychological Corporation. 
Blom, E. \& Boerma, T. (2016). Why do children with language impairment have difficulties with narrative macrostructure? Research in Developmental Disabilities, 55, 301-311.

Boerma, T., Leseman, P., Timmermeister, M., Wijnen, F., \& Blom, E. (2016). Narrative abilities of monolingual and bilingual children with and without language impairment: implications for clinical practice. International Journal of Language and Communication Disorders, 51(6), 626-638.

Cain, K. (2003). Text comprehension and its relation to coherence and cohesion in children's fictional narratives. British Journal of Developmental Psychology, 21, 335-351.

Cain, K. \& Oakhill, J. (1996). The nature of the relationship between comprehension skill and the ability to tell a story. British Journal of Developmental Psychology, 14, 187-201.

Colozzo, P., Gillam, R. B., Wood, M., Schnell, R. D., \& Johnston, J. R. (2011). Content and form in the narratives of children with specific language impairment. Journal of Speech, Language, and Hearing Research, 54, 1609-1627.

Duinmeijer, I., de Jong, J., \& Scheper, A. (2012). Narrative abilities, memory and attention in children with a specific language impairment. International Journal of Language and Communication Disorders, 47(5), 542-555.

Epstein, S.-A. \& Phillips, J. (2009). Storytelling skills of children with specific language impairment. Child Language Teaching and Therapy, 25, 285-300.

Fichman, S., Altman, C., Voloskovich, A., Armon-Lotem, S., \& Walters, J. (2017). Story grammar elements and causal relations in the narratives of Russian-Hebrew bilingual children with SLI and typical language development. Journal of Communication Disorders, 69, 72-93.

Gagarina, N., Klop, D., Kunnari, S., Tantele, K., Välimaa, T., Balčiūnienė, I., Bohnacker, U., \& Walters, J. (2012). MAIN: Multilingual Assessment Instrument for Narratives. ZASPil 56 - December 2012. Berlin: ZAS.

Habermas, T. \& de Silveira, C. (2008). The development of global coherence in life narratives across adolescence: Temporal, Causal, and Thematic Aspects. Developmental Psychology, 44, 707-721.

Halliday, M. A. K. (1994). Introduction to Functional Grammar. London: Arnold.

Hao, Y., Sheng, L., Zhang, Y., Jiang, F., de Villiers, J., Lee, W., \& Liu, X. L. (2017). A narrative evaluation of Mandarin-speaking children with language impairment. Journal of Speech, Language, and Hearing Research, 1-15.

Hayward, D. V., Gillam, R. B., \& Lien, P. (2007). Retelling a script-based story: Do children with and without language impairments focus on script and story elements? American Journal of Speech-Language Pathology, 16, 235-245.

Hedberg, N. L. \& Stoel-Gammon, C. (1986). Narrative analysis: Clinical procedures. Topics in Language Disorders, 7, 58-69.

Horn, L. R. (1997). Presupposition and implicature. In S. Lappin (Ed.), The Handbook of Contemporary Semantic Theory, (pp. 299-320). Oxford: Blackwell Handbooks in Linguistics.

Justice, L. M., Bowles, R., Pence, K., \& Gosse, C. (2010). A scalable tool for assessing children's language abilities within a narrative context: The NAP (Narrative Assessment Protocol). Early Childhood Research Quarterly, 25(2), 218-234. 
Kornev, A. N. (2006). Osnovy logopatologii detskogo vozrasta: klinicheskiye i psikhologicheskiye aspekty [The basics of developmental logopathology: Clinical and psychological issues]. St. Petersburg: Rechj.

Kornev, A. N. \& Balčiūnienè, I. (2014). Story (re-)telling and reading in children with dyslexia: Language or cognitive resource deficit? In LSCD 2014: Workshop on Late Stages in Speech and Communication Development, (pp. 23-26). London: UCL.

Kornev, A. N. \& Balčiūnienè, I. (2015). Narrative production weakness in Russian dyslexics: Linguistic or procedural limitations? Estonian Papers in Applied Linguistics, 11, 141-157.

Kornev, A. N. \& Balčiūnienè, I. (2017). Fictional narrative as a window to discourse development: A psycholinguistic approach. In J. Badio (Ed.), Events and Narratives in Language, (pp. 171-188). Frankfurt am Main-Bern- Bruxelles-New York-OxfordWarszawa-Wien: Peter Lang Publishing.

Newman, R. M. \& McGregor, K. K. (2016). Teachers and laypersons discern quality differences between narratives produced by children with or without SLI. Journal of Speech, Language, and Hearing Research, 49(5), 1022-1036.

Peterson, C. \& McCabe, A. (1991). Linking children's connective use and narrative macrostructure. In A. McCabe \& C. Peterson (Eds.), Developing Narrative Structure, (pp. 29-53). Hillsdale, NJ: Erlbaum.

Pinto, G., Tarchi, C., \& Bigozzi, L. (2015). The relationship between oral and written narratives: A three-year longitudinal study of narrative cohesion, coherence, and structure. British Journal of Educational Psychology, 85(4), 551-569.

Pinto, G., Tarchi, C., \& Bigozzi, L. (2016). Development in narrative competences from oral to written stories in five- to seven-year-old children. Early Childhood Research Quarterly, 36, 1-10.

Reuterskiöld, C., Hansson, K., \& Sahlén, B. (2011). Narrative skills in Swedish children with language impairment. Journal of Communication Disorders, 44(6), 733-744.

Sah, W. H. (2013). The development of coherence in narratives: Causal relations. In the 27th Pacific Asia conference on language, information, and computation - PACLIC-27 (pp. 173-180).

Sanders, T. (2005). Coherence, causality and cognitive complexity in discourse. In Proceedings/Actes SEM-05, First International Symposium on the Exploration and Modeling of Meaning, (pp. 105-114).

Schneider, P., Hayward, D. V., \& Vis Dubé, R. (2006). Storytelling from pictures using the Edmonton Narrative Norms Instrument. Journal of Speech-Language Pathology and Audiology, 30(4), 224-238.

Scott, C. M. (1988). Producing complex sentences. Topics in Language Disorders, 8(4), 44-62.

Shapiro, L. R. \& Hudson, J. A. (1991). Tell me a make-believe story: Coherence and cohesion in young children's picture-elicited narratives. Developmental Psychology, 27, 960-974.

Stein, N. L. \& Albro, E. R. (1997). Building complexity and coherence: Children's use of goal-structured knowledge in telling stories. In M. Bamberg (Ed.), Narrative Development: Six Approaches, (pp. 5-44). Mahwah, NJ: Erlbaum. 
Stein, N. L. \& Glenn, C. G. (1975). An Analysis of Story Comprehension in Elementary School Children: A Test of a Schema. Washington: Washington University.

Squires, K. E., Lugo-Neris, M. J., Peña, E. D., Bedore, L. M., Bohman, T. M., \& Gillam, R. B. (2014). Story retelling by bilingual children with language impairments and typically developing controls. International Journal of Language and Communication Disorders, 49(1), 60-74.

Trabassco, T. \& Sperry, L.L. (1985). Causal relatedness and importance of story events. Journal of Memory and Language, 24(5), 595-611.

Tribushinina, E., Dubinkina, E., \& Sanders, T. (2015). Can connective use differentiate between children with and without specific language impairment? First Language, $35,3-26$. 